\title{
Aspergillus fumigatus L-Amino Acid Oxidase-Two Step Purification and Characterization of the Enzyme
}

\author{
Susmita Singh ${ }^{1,2 *}$, Binod Kumar Gogoi ${ }^{1}$ and Rajib Lochan Bezbaruah ${ }^{1}$
}

${ }^{1}$ Biotechnology Division, North East Institute of Science and Technology (CSIR), Assam, India

${ }^{2}$ Department of Molecular Biology \& Biotechnology, Tezpur University, Assam, India

\begin{abstract}
L-amino acid oxidase (L-aao) obtained from Aspergillus fumigatus was purified by ion exchange and gel filtration chromatographies. The yield of L-aao in the ion- exchange chromatography was $24.40 \%$ while the recovery of purified L-aao by gel filtration was $18.70 \%$ of the crude enzyme. The molecular mass of the purified enzyme was estimated to be $55 \mathrm{kDa}$ by SDS PAGE and $93 \mathrm{kDa}$ by gel filtration. The enzyme was stable up to $40^{\circ} \mathrm{C}$ and over a broad $\mathrm{pH}$ range of 5.6-9.2. The enzyme has higher specificity towards hydrophobic aromatic L-amino acids namely tyrosine and phenylalanine. The kinetic parameters, $\mathrm{Km}$ and $\mathrm{Vmax}$ were determined as $43.47 \mathrm{mM}$ and $0.0434 \mu \mathrm{mol} /$ $\mathrm{min} / \mathrm{mL}$ respectively. Ten $\mathrm{mM}$ Benzoic acid and EDTA completely inhibited the enzyme, while minimum inhibition with glycine $(29.56 \%)$ and $\alpha$-napthol $(12.4 \%)$ were observed. Riboflavin, sodium azide and 8-hydroxyquinoline inhibit the enzyme up to $44.89 \%, 49.63 \%$ and $70.07 \%$ respectively. $\mathrm{MgSO}_{4}$ at $10^{-4} \mathrm{M}$ and $10^{-3} \mathrm{M}$ increased the enzyme activity by 1.72 and 2.22 fold respectively, while $\mathrm{CuSO}_{4}$ at $10^{-3} \mathrm{M}$ increased the activity by 1.65 fold. This is the first report of purification of L-aao from Aspergillus fumigatus.
\end{abstract}

Keywords: L-amino acid oxidase; Aspergillus fumigatus; Purification; Characterization

\section{Introduction}

The enzyme L-amino acid oxidase (L-amino acid: $\mathrm{O}_{2}$ oxido reductase, EC 1.4.3.2) (L-aao) is a flavo-enzyme that catalyses the oxidative deamination of $\mathrm{L}$-amino acid substrate into an $\alpha$-keto acid with the production of ammonia and hydrogen peroxide. L-aao catalyses the oxidative deamination of a number of L-amino acids, following the chemical reaction,

$\mathrm{H}_{2} \mathrm{NCHRCOOH}+\mathrm{O}_{2}+\mathrm{H}_{2} \mathrm{O} \rightarrow \mathrm{O}=\mathrm{CRCOOH}+\mathrm{NH}_{3}+\mathrm{H}_{2} \mathrm{O}_{2}$.

These enzymes are widely distributed across diverse phyla from bacteria to mammals including many venomous snakes $[1,2]$. L-aao in microorganisms is involved in the utilization of nitrogen sources [3] and those in animals have been characterized as having distinct biological and physiological functions. The function of snake venom L-aao is still poorly understood, although they play a role in inducing apoptosis, affect platelets and are considered to be toxins [4].

Much work has been done on snake venom $\mathrm{L}$-aao and the purification of $\mathrm{L}$-aao from various snake venoms has been reported by several groups [5-8].

There are very few reports of fungal, especially Aspergillus L-aao [9]. Few workers report the purification of L-aao from fungi and bacteria. L-aao was purified from Neurospora crassa by combination of ammonium sulphate precipitation, gel filtration and DEAE cellulose chromatography [10]. A novel L-glutamate oxidase was purified to homogeneity from Streptomyces endus [11]. The gram positive bacterium Rhodococcus opacus produces an L-aao which was purified to a high degree of homogeneity [12].

Previously, the optimization of medium and cultivation conditions for maximum production of L-aao from Aspergillus fumigatus [13] and the ability of Aspergillus fumigatus L-aao to cause the racemic resolution of DL-amino acids were reported by us [14]. In this communication, we report the purification of Aspergillus fumigatus $\mathrm{L}$-aao and characterization of the enzyme thereof.

\section{Materials and Methods}

\section{Chemicals}

The chemicals used were commercially available and of reagent grade. The chemicals were purchased from Qualigens, Merck, HiMedia and Sigma.

\section{Microorganism and culture condition}

Aspergillus fumigatus (Gene Bank Accession No: FJ765414) was cultivated in a medium containing (gl-1): glucose $10 ; \mathrm{Na}_{2} \mathrm{HPO}_{4} 2.5$; $\mathrm{KH}_{2} \mathrm{PO}_{4} 2 ;\left(\mathrm{NH}_{4}\right) 2 \mathrm{SO}_{4} 4$; yeast extract 4 ; and metal salts; $\mathrm{MgSO}_{4} .7 \mathrm{H}_{2} \mathrm{O}$ $0.5 ; \mathrm{CaCl}_{2} .2 \mathrm{H}_{2} \mathrm{O} .0 .5 ; \mathrm{H}_{3} \mathrm{BO}_{3} 0.05 ; \mathrm{Na}_{2} \mathrm{MoO}_{4} 0.04 ; \mathrm{ZnSO}_{4} .7 \mathrm{H}_{2} \mathrm{O} 0.04$; $\mathrm{CuSO}_{4} .7 \mathrm{H}_{2} \mathrm{O} 0.02 ; \mathrm{FeSO}_{4} .7 \mathrm{H}_{2} \mathrm{O} 0.02$ and DL-alanine $20 \mathrm{mM}$ as inducer, $\mathrm{pH} 7.0$ at $30^{\circ} \mathrm{C}$, in a shaking speed of $200 \mathrm{rpm}$.

\section{Isolation of $\mathrm{L}$-aao crude enzyme}

Aspergillus fumigatus cells ( $96 \mathrm{~h}$ ) were harvested by centrifugation at $9400 \mathrm{~g}$ and $10^{\circ} \mathrm{C}$, for 10 minutes (Sigma Centrifuge $30 \mathrm{~K}$, Osterode am Harz, Germany). The cells (38.4 g, wet weight) were then homogenized in a French pressure cell press (Thermo spectronic, Rochester, New York, USA) at 1500 psi for 5 minutes in ice cold condition. The cell suspension obtained was centrifuged at $13600 \mathrm{~g}$ for 15 minutes at $5^{\circ} \mathrm{C}$. The cell debris was discarded and the clear supernatant was taken as the crude enzyme.

${ }^{*}$ Corresponding author: Dr. Susmita Singh, Department of Molecular Biology \& Biotechnology, Tezpur University, Napaam-784028, Assam, India, Tel: +919957722523; E-mail: susmitasingh123@gmail.com

Received December 13, 2013; Accepted February 06, 2014; Published February 11,2014

Citation: Singh S, Gogoi BK, Bezbaruah RL (2014) Aspergillus fumigatus L-Amino Acid Oxidase-Two Step Purification and Characterization of the Enzyme. J Microb Biochem Technol 6: 096-101. doi:10.4172/1948-5948.1000128

Copyright: () 2014 Singh S, et al. This is an open-access article distributed under the terms of the Creative Commons Attribution License, which permits unrestricted use, distribution, and reproduction in any medium, provided the original author and source are credited 


\section{Protein concentration determination}

Protein concentration determination was done by the method of Lowry et al. [15], by taking Bovine albumin fraction V (Sigma, USA) as the standard protein.

\section{L-amino acid oxidase assay}

The assay of L-aao activity was carried out by measuring the formation of keto acid according to the method of Jian et al. [16], with slight modifications.

$0.5 \mathrm{~mL}(1.2 \mathrm{mg})$ of the enzyme was allowed to react with $0.5 \mathrm{~mL}$ of $100 \mathrm{mM}$ of substrate (DL-alanine, unless otherwise stated) in 50 $\mathrm{mM}$ of sodium phosphate buffer, $\mathrm{pH} 7.2$ for $1 \mathrm{~h}$ at $30^{\circ} \mathrm{C}, 200 \mathrm{rpm}$. After the reaction, a total of $0.5 \mathrm{~mL}$ of the reaction mixture was diluted 5 times with distilled water and reacted with $0.4 \mathrm{~mL}$ of 2 , 4-dinitrophenylhydrazine $(0.2 \%$ saturated in $2 \mathrm{~N} \mathrm{HCl})$ for 10 minutes. To this $1.5 \mathrm{~mL}$ of $3 \mathrm{M} \mathrm{NaOH}$ was added and absorbance at $550 \mathrm{~nm}$ was recorded after 15 minutes. Respective blanks and controls were also taken during the assay. One unit of $\mathrm{L}$-aao activity is defined as the amount of enzyme that produces $1 \mu \mathrm{mol}$ of pyruvate / minute $/ \mathrm{ml}$ of enzyme, under the conditions described above.

\section{Purification of A. fumigatus L-aao}

Ammonium sulphate was added to the crude enzyme $(40 \mathrm{~mL})$ of A. fumigatus at increasing concentrations of $25-90 \%$ with continuous stirring at $5^{\circ} \mathrm{C}$. The mixture was kept overnight at $5^{\circ} \mathrm{C}$ for the precipitation of proteins to occur. The protein precipitate that was formed was centrifuged at $13,600 \mathrm{~g}$ for 15 minutes at $5^{\circ} \mathrm{C}$. The supernatant was discarded, the protein pellet was dissolved in minimal volume $(6 \mathrm{~mL})$ of $50 \mathrm{mM}$ sodium phosphate buffer, $\mathrm{pH} 7.2$ and dialysed against 10 $\mathrm{mM}$ sodium phosphate buffer, $\mathrm{pH} 7.2$ and then concentrated in a freeze dryer (Eyela, Tokyo Rikakikai Co. Ltd. ) to $1 \mathrm{~mL}$. This was then applied to a DEAE Sephadex A-50 column $(30 \times 1.8 \mathrm{~cm})$ previously equilibrated with the same buffer. An increscent concentration gradient from $0^{-1} \mathrm{M}$ $\mathrm{NaCl}$ in $10 \mathrm{mM}$ sodium phosphate buffer, $\mathrm{pH} 7.2$ was applied to elute the fractions ( $5 \mathrm{~mL}$ per tube). The flow rate was kept at $0.5 \mathrm{~mL} / \mathrm{min}$ and the elution profile was monitored at $280 \mathrm{~nm}$ of absorbance. Fractions with L-aao activity were pooled and concentrated in a freeze dryer to $1 \mathrm{~mL}$. This was then applied to a Sephadex G-75 column $(65 \times 1.5 \mathrm{~cm})$ pre-equilibrated with $10 \mathrm{mM}$ sodium phosphate buffer, $\mathrm{pH} 7.2$ which was also used for the elution of the fractions ( $2 \mathrm{~mL}$ per tube) at a flow rate of $0.7 \mathrm{~mL} / \mathrm{min}$. The L-aao activity of the fractions was measured with $0.5 \mathrm{~mL}$ of the fractions as stated previously. The active fractions were stored at $5^{\circ} \mathrm{C}$ until use.

\section{Estimation of catalase activity}

The estimation of catalase activity was done qualitatively by observing the evolution of $\mathrm{O}_{2}$ that was seen when $50 \mu \mathrm{L}$ of the fraction was added to $0.5 \mathrm{~mL}$ of $1 \%(\mathrm{v} / \mathrm{v}) \mathrm{H}_{2} \mathrm{O}_{2}$. The fractions showing evolution of $\mathrm{O}_{2}$ were catalase positive.

\section{Determination of molecular weight of $\mathrm{L}$-aao}

SDS-PAGE was carried out in a $12 \%$ Polyacrylamide gel following the method of Laemmli [17]. The gel was stained with Coomassie brilliant blue R-250 and a prestained Molecular weight marker MW 27,000-180,000 (Sigma, USA); $180 \mathrm{kDa}, 116 \mathrm{kDa}, 90 \mathrm{kDa}, 58 \mathrm{kDa}$, $36.5 \mathrm{kDa}, 26.6 \mathrm{kDa}$, was taken to estimate the molecular weight of the band. The molecular weight of the native protein was estimated by size exclusion chromatography on Sephadex G-75 column. Blue dextran
2000 was used to calculate the void volume $\left(\mathrm{V}_{0}\right)$ of the column. The molecular weight standards used were glucose oxidase $(200 \mathrm{kDa})$; fructose 6-phosphate kinase $(84 \mathrm{kDa})$; ovalbumin $(45 \mathrm{kDa})$ and carbonic anhydrase $(29 \mathrm{kDa})$. The elution was carried out with $10 \mathrm{mM}$ sodium phosphate buffer, $\mathrm{pH} 7.2$ at a flow rate of $0.5 \mathrm{~mL} / \mathrm{min}$.

\section{High performance reverse-phase column analysis}

The purified L-aao was loaded on a reverse-phase C18 HPLC column (Novapack, 3.9 x150 mm, Waters). Elution buffer A was $0.1 \%$ $(\mathrm{v} / \mathrm{v})$ Trifluoroacetic acid (TFA) in acetonitrile; elution buffer B was $0.1 \%(\mathrm{v} / \mathrm{v})$ TFA in HPLC grade water. The column was eluted with a linear gradient (100\% A for 0-5 min; 0-75\% B for 5-25 min; 100\% B for 25-30 min).

\section{Characterization of $\mathrm{L}$-aao}

pH optima, temperature optima and heat inactivation of L-aao: For the $\mathrm{pH}$ optima, $50 \mathrm{mM}$ buffers of different $\mathrm{pH}$ i.e. sodium acetate ( $\mathrm{pH} 4.0,5.6)$; sodium phosphate $(\mathrm{pH}$ 6.0, 7.2); Tris- $\mathrm{HCl}(\mathrm{pH} 8.8)$ and carbonate-bicarbonate buffer $(\mathrm{pH} 9.2,10.0)$ were used under the standard assay conditions. For determining the temperature optima of the enzyme, the reaction temperature was varied from $25^{\circ} \mathrm{C}$ to $35^{\circ} \mathrm{C}$, at $\mathrm{pH}$ 7.2. The heat inactivation of the A. fumigatus $\mathrm{L}$-aao was performed by incubating the enzyme at temperatures from $40^{\circ}$ to $90^{\circ} \mathrm{C}$ for $5-10$ minutes at $\mathrm{pH}$ 7.2. The effect of heat inactivation in the presence of substrate was determined by taking $50 \mathrm{mM}$ of DL-alanine during the study.

Substrate specificity and enzyme kinetics: The substrate specificity of the enzyme was tested against various DL-/L- and D-amino acids. The substrates were added in $50 \mathrm{mM}$ concentration and the enzyme $(2.4 \mathrm{mg} / \mathrm{mL})$ activity was performed under standard assay conditions as stated previously.

The kinetic parameters $\mathrm{Km}$ and Vmax were determined by taking DL-alanine as the substrate.

Effect of inhibitors and metal ions on L-aao activity: The effect of inhibitors on the activity of the enzyme was investigated by adding $10 \mathrm{mM}$ of the inhibitors ( $\alpha$-napthol, EDTA, Glycine, Sodium azide, 8-hydroxyquinolone, Benzoic acid and Riboflavin) in the reaction mixture. After the reaction, the reaction mixture was centrifuged at $9400 \mathrm{~g}$ for 10 minutes and the assay was done with $0.5 \mathrm{~mL}$ as described previously.

The effect of metal ions $\left(\mathrm{MgSO}_{4}, \mathrm{CaCl}_{2}, \mathrm{H}_{3} \mathrm{BO}_{3}, \mathrm{Na}_{2} \mathrm{MO}_{4}, \mathrm{ZnSO}_{4}\right.$, $\mathrm{CuSO}_{4}$ and $\mathrm{FeSO}_{4}$ ) on enzyme activity was investigated by adding the metal ions in the reaction mixture at $10^{-4} \mathrm{M}$ and $10^{-3} \mathrm{M}$ concentration and performing the enzyme reaction.

\section{Results}

\section{Purification of L-aao from A. fumigatus}

Following ion-exchange chromatography on DEAE Sephadex A-50, the enzyme was eluted in a single peak, fraction F1 (Figure 1a) Catalase was co-eluted along with the L-aao (results not shown). Fraction F1 was further separated into 2 peaks on a Sephadex G-75 column, of which L-aao activity was detected in fraction F2 (Figure $1 b)$. The catalase was separated from the L-aao at this step which was confirmed by the qualitative catalase test. The protein yield of this purification is shown in Table 1 . The homogeneity of purified L-aao was corroborated by C18 RP-HPLC which showed one major peak (Figure 2c). The minor peak that was seen was that of the solvent. 

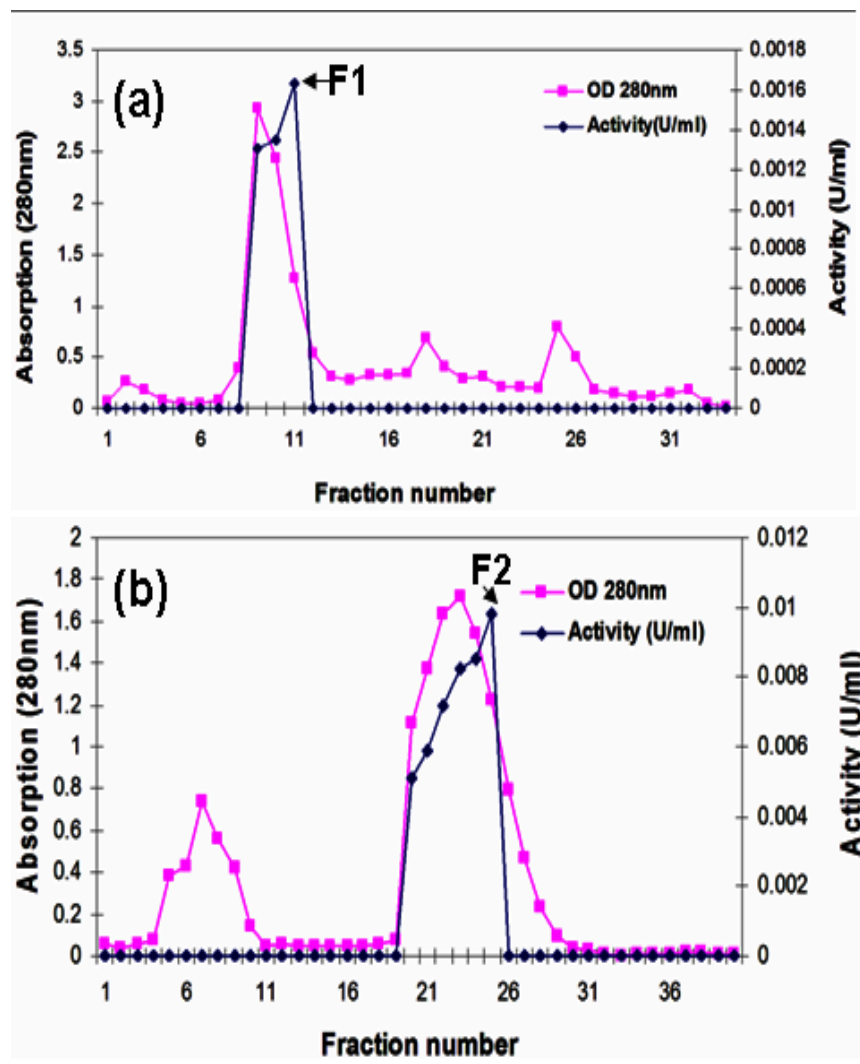

Figure 1: Purification profile of A.fumigatus L-aao. (a) lon-exchange chromatography of crude enzyme on a DEAE-Sephadex A-50 column. The column $(30 \times 1.8 \mathrm{~cm})$ was pre-equilibrated with $10 \mathrm{mM}$ sodium-phosphate buffer $(\mathrm{pH} 7.2)$. Elution was done with a linear concentration gradient of $\mathrm{NaCl}\left(0^{-1} \mathrm{M}\right)$ at a flow rate of $0.5 \mathrm{~mL} / \mathrm{min}$. Fraction $\mathrm{F} 1$ (indicated by an arrow) containing L-aao activities were pooled and lyophilized. (b) Gel filtration chromatography on a Sephadex G-75 column. Fraction F1 was loaded on a Sephadex G-75 column $(65 \times 1.5 \mathrm{~cm})$ pre-equilibrated with $10 \mathrm{mM}$ sodium phosphate buffer $(\mathrm{pH}$ 7.2 ) and eluted with the same buffer at a flow rate of $0.7 \mathrm{~mL} / \mathrm{min}$. Fractions with L-aao activity were pooled and lyophilized (Fraction F2, indicated by an arrow).

The purified A. fumigatus L-aao migrated as a single band in SDSPAGE under reducing condition. The molecular mass of purified L-aao was found to be $55 \mathrm{kDa}$ as estimated from SDS-PAGE (Figure 2a). The apparent molecular weight of $A$. fumigatus $\mathrm{L}$-aao was $93 \mathrm{kDa}$ as determined by gel filtration chromatography (Figure $2 \mathrm{~b}$ ), which suggests that the A. fumigatus $\mathrm{L}$-aao is a dimeric protein.

\section{pH optima, temperature optima and heat inactivation of} L-aao

The A. fumigatus $\mathrm{L}$-aao is stable over a broad $\mathrm{pH}$ range i.e. 5.6-9.2 and the highest enzyme activity is found at $\mathrm{pH} 7.2$ (Figure 3a). The enzyme activity was maximum at $30^{\circ} \mathrm{C}$ of reaction temperature, while the enzyme activity was $88.78 \%$ and $41.98 \%$ of the activity at $30^{\circ} \mathrm{C}$, at reaction temperatures $25^{\circ} \mathrm{C}$ and $35^{\circ} \mathrm{C}$ respectively. The enzyme is stable over temperatures up to $40^{\circ} \mathrm{C}$ although loss in enzyme activity is seen. Treatment of the enzyme at $40^{\circ} \mathrm{C}$ and $50^{\circ} \mathrm{C}$ for 5 minutes causes $38.47 \%$ and $67.19 \%$ loss in activity as compared to the activity of the untreated enzyme. When the time of incubation of the enzyme at $40^{\circ} \mathrm{C}$ and $50^{\circ} \mathrm{C}$ is increased to 10 minutes, total loss of enzyme activity occurs. Treatment of the enzyme at higher temperatures of $60^{\circ} \mathrm{C}-90^{\circ} \mathrm{C}$ for 5 minutes completely inactivates the enzyme.

\section{Substrate specificity and enzyme kinetics}

The best substrates were found to be DL-tyrosine and L-phenylalanine, which are aromatic amino acids. L-amino acids like L-threonine, L-cystin, L-tryptophan, L-glutamic acid are not attacked by the enzyme. Also there was no activity against the basic amino acid $\mathrm{L}$-arginine. No enzyme activity was detected against the D-amino acids. Table 2 gives a comparison of the enzyme activity with different substrates.

The substrate saturation kinetics of the enzyme was investigated with DL-alanine as the substrate. The enzyme activity increased simultaneously with increasing substrate concentration and reached its maximum at $100 \mathrm{mM}$. The activity at $150 \mathrm{mM}$ and $200 \mathrm{mM}$ were
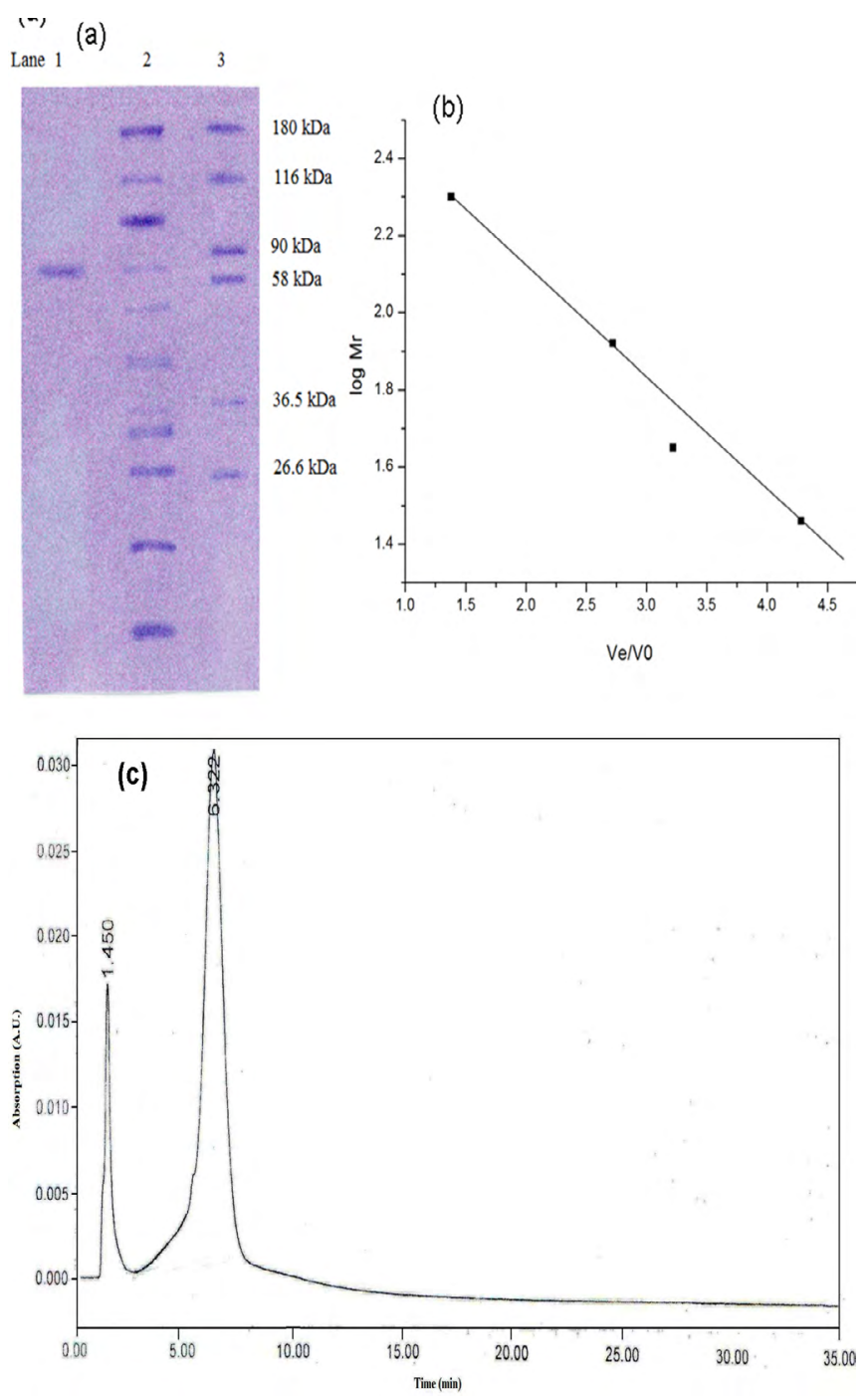

Figure 2: (a) SDS-PAGE of purified L-aao. Lane 1 - Purified A. fumigatus L-amino acid oxidase, lane 2- Crude enzyme, lane 3- Standard protein ladder (Prestained Molecular weight marker MW 27,000-180,000; Sigma). (b) Molecular weight determination by size exclusion chromatography on Sephadex G-75. The molecular weight standards used were glucose oxidase ( $V / V_{0}=1.38$ ); fructose 6-phosphate kinase $(V / V=2.72)$; ovalbumin $\left(\mathrm{V}_{\mathrm{e}} / \mathrm{V}_{0}=3.22\right)$ and carbonic anhydrase $\left(\mathrm{V}_{\mathrm{e}} / \mathrm{N}_{0}=4.11\right)$. $\mathrm{V}_{\mathrm{e}} \mathrm{N}_{0}$ of $A$. fumigatus $\mathrm{L}$-aao=2.55. (c) The purity of the $\mathrm{L}$-aao was determined by reverse-phase $\mathrm{C} 18$ HPLC column (Novapack, $3.9 \times 150 \mathrm{~mm}$ ). The peak at retention time 6.322 signifies the purified enzyme. 
almost equal to the activity at $100 \mathrm{mM}$. The substrate saturation graph was drawn by plotting the substrate concentration vs. the velocity of reaction (Figure $3 \mathrm{~b}$ ). The kinetic parameter, $\mathrm{Km}$ was $43.47 \mathrm{mM}$ and Vmax was $0.0434 \mu \mathrm{mol} / \mathrm{min} / \mathrm{mL}$ as determined from the Lineweaver Burk plot (Figure 3c).

\section{Effect of inhibitors and metal ions on L-aao activity}

The compounds had inhibitory effects up to various degrees (Table 3 ). Benzoic acid and EDTA, at concentration of $10 \mathrm{mM}$ completely inhibited the enzyme. The enzyme showed minimum inhibition with glycine (29.56\%) while $\alpha$-napthol inhibited the enzyme up to $12.4 \%$ only. Riboflavin and sodium azide inhibits the enzyme moderately up to $44.89 \%$ and $49.63 \%$ respectively while 8 -hydroxyquinoline inhibits the enzyme up to $70.07 \%$.

$\mathrm{MgSO}_{4}$ at $10^{-4} \mathrm{M}$ and $10^{-3} \mathrm{M}$ both increased the enzyme activity by 1.72 and 2.22 fold respectively, while $\mathrm{CuSO}_{4}$ at $10-3 \mathrm{M}$ increased the enzyme activity by 1.65 fold (Figure $3(\mathrm{~d})$ ). The metal salts like $\mathrm{Ca}^{2+}$, $\mathrm{H}_{3} \mathrm{BO}_{3}, \mathrm{Na}_{2} \mathrm{MO}_{4}, \mathrm{Zn}^{2+}$, and $\mathrm{FeSO}_{4}$ did not have positive effect and inhibited the enzyme activity up to various degrees.

\begin{tabular}{|l|c|c|c|c|c|c|}
\hline Step & Vol. (mL) & Total A. (U) & Total Prot. (mg) & S.A.(U/mg) & Yield (\%) & $\begin{array}{c}\text { Purif. } \\
\text { fold }\end{array}$ \\
\hline Crude & 40 & 1.23 & 96.8 & 0.012 & 100 & 1 \\
\hline ASF & 6 & 0.92 & 38 & 0.024 & 74.8 & 2 \\
\hline IEC & 14 & 0.3 & 7 & 0.043 & 24.4 & 3.6 \\
\hline GFC & 12 & 0.23 & 1.9 & 0.121 & 18.7 & 10 \\
\hline
\end{tabular}

ASF- ammonium sulphate fractionation; IEC- Ion Exchange Chromatography on DEAE Sephadex A-50; GFC- gel fractionation chromatography on Sephadex G-75 A. = Activity; S.A. = Specific Activity

Table 1: Purification table for A. fumigatus L-aao.

\begin{tabular}{|l|c|c|}
\hline Substrate (50mM) & $\mathbf{U} / \mathbf{m L}$ & \% R.. $\mathbf{A}^{\mathbf{a}}$ \\
\hline DL-alanine & 0.028 & 42 \\
\hline L-alanine & 0.036 & 54.1 \\
\hline D-alanine & 0 & 0 \\
\hline DL-leucine & 0.037 & 55.6 \\
\hline L-methionine & 0 & 0 \\
\hline L-cystin & 0 & 0 \\
\hline L-phenylalanine & 0.051 & 76 \\
\hline DL-tyrosine & 0.067 & 100 \\
\hline L-tryptophan & 0 & 0 \\
\hline L-serine & 0.044 & 66 \\
\hline L-threonine & 0 & 0 \\
\hline L-aspartic acid & 0.009 & 13.2 \\
\hline L-glutamic acid & 0 & 0 \\
\hline L-arginine & 0 & 0 \\
\hline
\end{tabular}

a: \% Relative activity (i.e. activity with respect to maximum)

Table 2: Comparison of the enzyme activity with different substrates.

\begin{tabular}{|l|c|c|}
\hline Inhibitor & Units & \% Inhibition \\
\hline Nil & $0.0274 \pm 0.0008$ & 0 \\
\hline 8-hydroxyquinoline & $0.0082 \pm 0.0002$ & 70.07 \\
\hline EDTA & 0 & 100 \\
\hline Glycine & $0.0193 \pm 0.0004$ & 29.56 \\
\hline Sod.azide & $0.0138 \pm 0.0002$ & 49.63 \\
\hline a-napthol & $0.024 \pm 0.0025$ & 12.4 \\
\hline Riboflavin & $0.0151 \pm 0.0002$ & 44.89 \\
\hline Benzoic acid & 0 & 100 \\
\hline
\end{tabular}

The data are expressed as mean of three individual experiments \pm std.dev

Table 3: Effect of inhibitors on the A. fumigatus L-aao.

\section{Discussion}

In the present work, we purified a novel L-aao from Aspergillus fumigatus to a high degree of molecular homogeneity after two chromatographic steps. The yield of $\mathrm{L}$-aao in the ion- exchange chromatography was $24.40 \%$ while the recovery of purified L-aao by gel filtration was $18.70 \%$ of the crude enzyme. Co-elution of catalase occurred in DEAE Sephadex A-50 chromatography but catalase was separated from the L-aao during gel filtration. The molecular mass of A. fumigatus $\mathrm{L}$-aao was found to be $55 \mathrm{kDa}$ when estimated by SDSPAGE and the apparent molecular mass was found to be $93 \mathrm{kDa}$ as estimated by gel filtration chromatography which suggests that the enzyme is a dimeric protein, which is consistent with the molecular mass of Streptomyces endus L-aao $(50 \mathrm{kDa}$ by SDS-PAGE and $90 \mathrm{kDa}$ by gel chromatography) [11]; Rhodococcus opacus L-aao (53.2 kDa by SDS-PAGE and $99 \mathrm{kDa}$ by gel chromatography) [12] and that of snake venom L-aao like Daboia russellii siamensis L-aao (58.0 kDa) [18] and Agkistrodon contortrix laticinctus L-aao $(60 \mathrm{kDa})$ [19]. Snake venom $\mathrm{L}$-aao are usually homodimeric glycoproteins with a molecular mass of around $110-150 \mathrm{kDa}$ when measured by gel filtration. However, when assayed by SDS-PAGE, both under reducing as well as non-reducing conditions, the molecular mass is around $50-70 \mathrm{kDa}[6,20,21]$. The HPLC of the purified A. fumigatus L-aao in a RP C18 column showed one major peak of the enzyme and a minor peak corresponding to the solvent. This chromatogram pattern of the purified enzyme is similar to the Bothrops alternatus L-aao [6] and Bungarus fasciatus L-aao [22] which show a major peak corresponding to the purified enzyme and a peak corresponding to the solvent.

A. fumigatus L-aao is stable over a broad $\mathrm{pH}$ range of 5.6-9.2 with the highest enzyme activity detected at $\mathrm{pH} 7.2$. The $S$. endus L-glutamate oxidase was stable in the $\mathrm{pH}$ range of 5.5-7.5 [11], while the optimal activity of the R. opacus L-aao was at pH 8-9 [12]. The neutral, cell free $\mathrm{L}$-aao solution of Proteus vulgaris was stable for weeks at $0^{\circ} \mathrm{C}$ [23]. The stability decreased as the $\mathrm{pH}$ was lowered and below $\mathrm{pH} 4$ the enzyme was rapidly inactivated.

Crotalus adamanteus $\mathrm{L}$-aao was stable to heat $\left(70^{\circ} \mathrm{C}\right)$ in presence of L-leucine with only one third losses in activity after 60 minutes incubation [24]. However, treatment of the enzyme at $70^{\circ} \mathrm{C}$ in the absence of L-leucine lost all activity within 5 minutes. L-phenylalanine and L-methionine (at concentrations of $0.0091 \mathrm{M}$ ) also protected the enzyme from heat denaturation, whereas equimolar concentrations of D-leucine and L-lysine did not protect the enzyme and L-valine and L-alanine afforded less or no protection [24]. The R. opacus L-aao was greatly inhibited by incubation at temperatures above $37^{\circ} \mathrm{C}$ and there was almost total loss in enzyme activity when the enzyme was incubated for 5 minutes at $50^{\circ} \mathrm{C}$ [12]. Also, the $P$. vulgaris L-aao was unstable in neutral salt solution above $50^{\circ} \mathrm{C} .5$ minutes at $55^{\circ} \mathrm{C}$ destroyed $78 \%$ of the activity, while 5 minutes at $60^{\circ} \mathrm{C}$ destroyed all enzyme activity [23]. This is in compliance with our findings that A. fumigatus $\mathrm{L}$-aao is inhibited by temperatures above $40^{\circ} \mathrm{C}$. Treatment of the enzyme at $40^{\circ} \mathrm{C}$ and $50^{\circ} \mathrm{C}$ for 5 minutes causes $38.47 \%$ and $67.19 \%$ loss in activity as compared to the activity of the untreated enzyme. The presence of substrate $(50 \mathrm{mM}, \mathrm{DL}$-alanine) during the heat treatment did not offer any protection for our enzyme.

A. fumigatus L-aao shows a certain degree of substrate preference. The enzyme has a greater specificity towards hydrophobic aromatic amino acids namely DL-tyrosine and L-phenylalanine. D-amino acids are not attacked. The substrate specificity in decreasing order is 

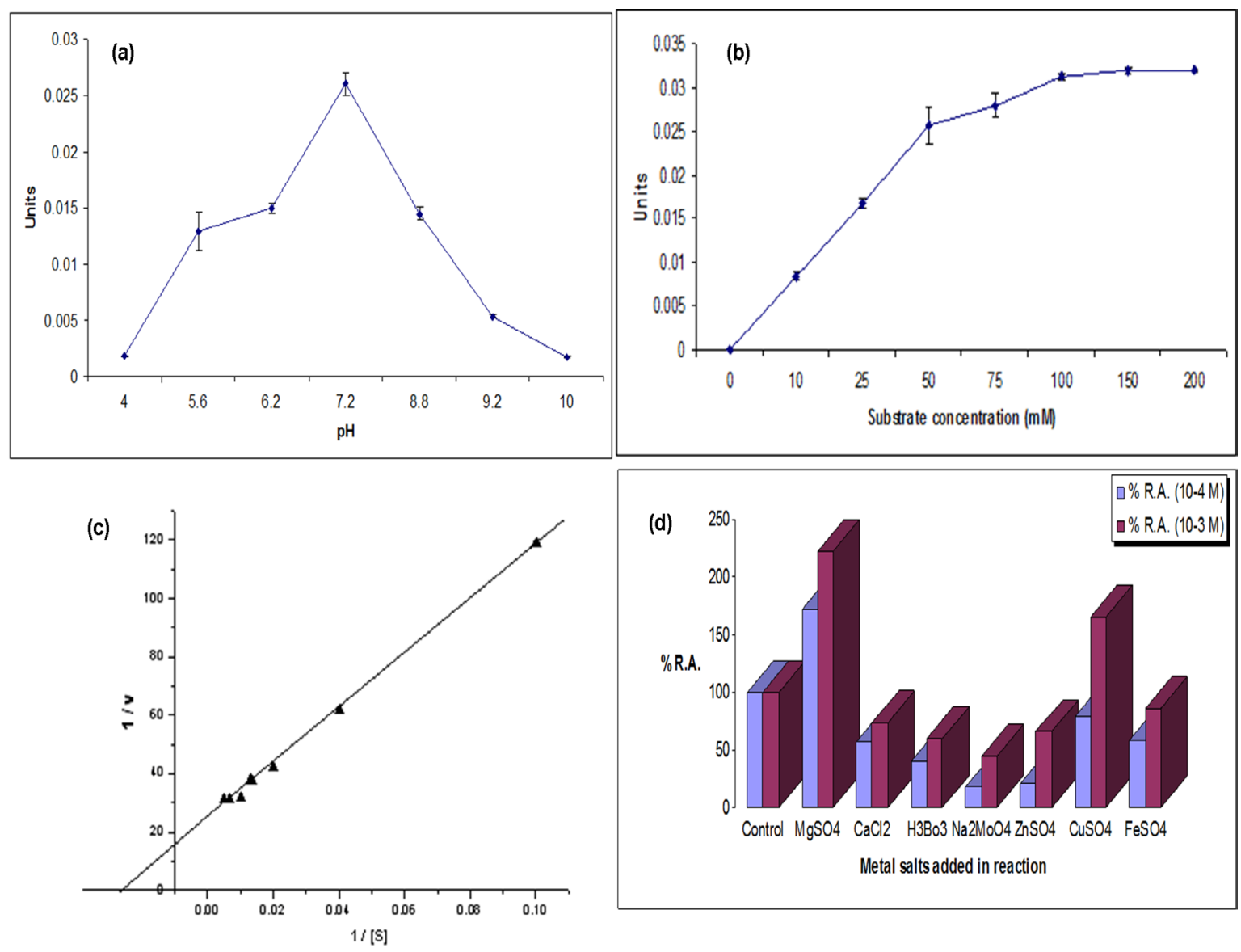

Figure 3: (a) Effect of buffer $\mathrm{pH}$ on the L-aao activity. (The experiment was done in triplicate and the data are expressed as mean \pm standard deviation). (b) Substrate saturation kinetics of $A$. fumigatus L-aao. (c) Lineweaver Burk plot of $A$. fumigatus L-aao. The intercept on the $\mathrm{x}$-axis i.e. $-1 / \mathrm{Km}=-0.023$ and the intercept on $\mathrm{y}$-axis i.e. $1 / \mathrm{vmax}=23$. Therefore $\mathrm{K}_{\mathrm{m}}=43.47$ and $\mathrm{Vmax}=0.0434 \mu \mathrm{mol} / \mathrm{min} / \mathrm{mL}$. (d) Effect of metal salts on the L-aao activity of $A$. fumigatus. The metal salts were added in $10^{-4}$ and $10^{-3} \mathrm{M}$ concentration during the enzyme reaction.

as follows Tyr $>$ Phe $>$ Ser $>$ Leu $>$ Ala $>$ Asp. The enzyme did not act on the tested basic amino acids. This is in disagreement with the $R$. opacus L-aao [12] and B. alternatus snake venom L-aao [6] since basic amino acids seemed to be good substrates for these organisms. The best substrates for the snake venom $\mathrm{L}$-aao are the L-isomers of phenylalanine, tyrosine, leucine, isoleucine, methionine and tryptophan $[5,19,25]$ and this is also true for A. fumigatus L-aao with the exception of L-methionine and L-tryptophan which are not recognized as substrates by this enzyme.

Benzoic acid and EDTA, at concentration of $10 \mathrm{mM}$ completely inhibited the enzyme. Klein and Kamin [26] studied the effect of benzoate on $\mathrm{D}$-amino acid oxidase and suggested that the inhibition was related to the formation of a benzoic acid-enzyme complex and the action of this inhibitor is mainly substrate competitive. This may be true for A. fumigatus L-aao since the benzoic acid completely inhibits the enzyme. Benzoic acid also inhibits Penicillium chrysogenum L-aao [27] and snake venom L-aao of Crotalus adamanteus [28], Trimeresursus mucrosquamatous [29] and Rattus norvegicus [28]. The Chlamydomonas reinhardtii L-aao was inhibited upto $90 \%$ by $10 \mathrm{mM}$ EDTA [30]. Napthol and glycine were found to inhibit the L-aao of Anacystis nidulans and $R$. opacus [12,31]. The activity of the $R$. opacus enzyme was strongly decreased by competitive inhibition in glycine buffer. This is in slight disagreement in our case, since A. fumigatus L-aao showed minimum inhibition with glycine (29.56\%) while a-napthol inhibited the enzyme upto $12.4 \%$ only. Sodium azide was reported to be an inhibitor of L-aao of A. nidulans [31] and Proteus sp. [32] and this was also true for the A. fumigatus enzyme which is inhibited upto $49.63 \%$. Riboflavin inhibits the A. fumigatus enzyme moderately upto $44.89 \%$ and this was also observed for L-aao of Bombyx mori [33]. Deurre et al. [34] found that 8-hydroxyquinoline is an inhibitor of Proteus rettgeri L-aao and this is also true for our enzyme.

$\mathrm{Ca}^{2+}, \mathrm{Zn}^{2+}, \mathrm{Mg}^{2+}$ and $\mathrm{Cu}^{2+}$ were reported to be inhibitors of $A$. nidulans $\mathrm{L}$-aao [31]. This was partly true for $A$. fumigatus $\mathrm{L}$-aao, which was inhibited by $\mathrm{Ca}^{2+}$ and $\mathrm{Zn}^{2+}$ but $\mathrm{Mg}^{2+}$ and $\mathrm{Cu}^{2+}$ activated the enzyme up to many fold.

\section{Acknowledgements}

The financial assistance received from Council of Scientific and Industria Research in the form of Senior Research Fellowship to S. S. is duly acknowledged.

The authors thank Dr.P.G.Rao, Director, NEIST, Jorhat for providing the facilities for carrying out the work. Author S.S. also acknowledges UGC's Dr. D. S. Kothari Post-Doctoral Fellowship scheme for providing facility during writing of the manuscript. 
Citation: Singh S, Gogoi BK, Bezbaruah RL (2014) Aspergillus fumigatus L-Amino Acid Oxidase-Two Step Purification and Characterization of the Enzyme. J Microb Biochem Technol 6: 096-101. doi:10.4172/1948-5948.1000128

\section{References}

1. Meister A (1957) Biochemistry of the amino acids. Academic Press Inc Publishers, New York.

2. Zeller EA and Martiz A (1944) Ueber eine neue I-Aminosaeure oxidase. Helv. Chim. Acta. 27:1888

3. Sikora L, Marzluf GA (1982) Regulation of L-amino acid oxidase and of D-amino acid oxidase in Neurospora crassa. Mol Gen Genet 186: 33-39.

4. Du XY, Clemetson KJ (2002) Snake venom L-amino acid oxidases. Toxicon 40: 659-665.

5. Wei XL, Wei JF, Li T, Qiao LY, Liu YL, et al. (2007) Purification, characterization and potent lung lesion activity of an L-amino acid oxidase from Agkistrodon blomhoffii ussurensis snake venom. Toxicon 50: 1126-1139.

6. Stabeli RG, Marcussi S, Carlos GB, Pietro RCLR, Selistre-de-Araujo HS, et al (2004) Platelet aggregation and antibacterial effects of an L-amino acid oxidase purified from Bothrops alternatus snake venom. Bioorg Med Chem 12: 2881 2886.

7. Toyama MH, Toyama Dde O, Passero LF, Laurenti MD, Corbett CE, et al. (2006) Isolation of a new L-amino acid oxidase from Crotalus durissus cascavella venom. Toxicon 47: 47-57.

8. Kommoju PR, Macheroux P, Ghisla S (2007) Molecular cloning, expression and purification of L-amino acid oxidase from the Malayan pit viper Calloselasma rhodostoma. Protein Expr Purif 52: 89-95.

9. Davis MA, Askin MC, Hynes MJ (2005) Amino acid catabolism by an areAregulated gene encoding an L-amino acid oxidase with broad substrate specificity in Aspergillus nidulans. Appl Environ Microbiol 71: 3551-3555.

10. Niedermann DM, Lerch K (1990) Molecular cloning of the L-amino-acid oxidase gene from Neurospora crassa. J Biol Chem 265: 17246-17251.

11. Böhmer A, Müller A, Passarge $M$, Liebs $P$, Honeck $H$, et al. (1989) A nove L-glutamate oxidase from Streptomyces endus. Purification and properties. Eur J Biochem 182: 327-332.

12. Geueke B and Hummel W (2002) A new bacterial L-amino acid oxidase with a broad substrate specificity: purification and characterization. Enzyme and microbial technology 31: 77-87.

13. Singh S, Gogoi BK, Bezbaruah RL (2009) Optimization of medium and cultivation conditions for L-amino acid oxidase production by Aspergillus fumigatus. Can J Microbiol 55: 1096-1102.

14. Singh S, Gogoi BK, Bezbaruah RL (2011) Racemic resolution of some DLamino acids using Aspergillus fumigatus $L$-amino acid oxidase. Curr Microbio 63. $94-99$

15. LOWRY OH, ROSEBROUGH NJ, FARR AL, RANDALL RJ (1951) Protein measurement with the Folin phenol reagent. J Biol Chem 193: 265-275.

16. Jian Y, Dong-Yang L, Ying-Jiu Z, Sheng Y, Ren-bao L, Zhong-Yi Y (2002) High expression of Trigonopsis variabilis $\mathrm{D}$-amino acid oxidase in Pichia pastoris. Journal of Molecular Catalysis B: enzymatic 18: 291-297.

17. Laemmli UK (1970) Cleavage of structural proteins during the assembly of the head of bacteriophage T4. Nature 227: 680-685
18. Zhong SR, Jin $Y, W u$ JB, Jia $Y H, X u$ GL, et al. (2009) Purification and characterization of a new $L$-amino acid oxidase from Daboia russellii siamensis venom. Toxicon 54: 763-771.

19. Souza DH, Eugenio LM, Fletcher JE, Jiang MS, Garratt RC, et al. (1999) Isolation and structural characteriza

a cytotoxic L-amino acid oxidase from Agkistrodon contortrix laticinctus snake venom: preliminary crystallographic data. Arch Biochem Biophys 368: 285-290.

20. Butzke D, Hurwitz R, Thiede B, Goedert S, Rudel T (2005) Cloning and biochemical characterization of APIT, a new l-amino acid oxidase from Aplysia punctata. Toxicon 46: 479-489.

21. Torii S, Yamane K, Mashima T, Haga N, Yamamoto K, et al. (2000) Molecula cloning and functional analysis of apoxin I, a snake venom-derived apoptosisinducing factor with L-amino acid oxidase activity. Biochemistry 39: 3197-3205

22. Wei JF, Yang HW, Wei XL, Qiao LY, Wang WY, et al. (2009) Purification characterization and biological activities of the L-amino acid oxidase from Bungarus fasciatus snake venom. Toxicon 54: 262-271.

23. Stumpf PK and Green DE (1944) L-amino acid oxidase of Proteus vulgaris. J. Biol. Chem 153: 387-399

24. WELLNER D, MEISTER A (1960) Evidence for an intermediate in the oxidation of reduced L-amino acid oxidase by molecular oxygen. J Biol Chem 235: PC1213.

25. Izidoro LF, Ribeiro MC, Souza GR, Sant'Ana CD, Hamaguchi A, et al. (2006) Biochemical and functional characterization of an L-amino acid oxidase isolated from Bothrops pirajai snake venom. Bioorg Med Chem 14: 7034-7043.

26. Klein JR, Kamin H (1941) Inhibition of the D-amino acid oxidase by benzoic acid. J Biol Chem 138: 507-512.

27. Knight SG (1948) The I-amino acid oxidase of molds. J. Biochem. 55: 401-407

28. Meister A, Wellner D (1963) Flavoprotein amino acid oxidases. The Enzymes, 2nd Ed. 7: 609-648.

29. Ueda M, Chang CC, Ohno M (1988) Purification and characterization of L-amino acid oxidase from the venom of Trimeresurus mucrosquamatus (Taiwan habu snake). Toxicon 26: 695-706

30. Vallon O, Bulté L, Kuras R, Olive J, Wollman FA (1993) Extensive accumulation of an extracellular L-amino-acid oxidase during gametogenesis of Chlamydomonas reinhardtii. Eur J Biochem 215: 351-360.

31. Pistorius EK, Voss H (1980) Some properties of a basic L-amino-acid oxidase from Anacystis nidulans. Biochim Biophys Acta 611: 227-240.

32. CioacÄf C, Ivanof A (1974) Bacterial amino acid oxidases. I. L-amino acid oxidase and its distribution in bacteria. Arch Roum Pathol Exp Microbiol 33 211-222.

33. KOTAKA S (1963) The L-amino acid oxidase from silkworm eggs (Bombyx mor L.). J Gen Physiol 46: 1087-1094.

34. Duerre JA, Chakrabarty S (1975) l-amino acid oxidases of Proteus rettgeri. J Bacteriol 121: 656-663. 